\title{
Regional Analgesia in Intensive Care
}

\author{
Luísa Guedes ${ }^{1}$, Helena Rebelo ${ }^{1}$, Raquel Oliveira ${ }^{1}$, Aida Neves ${ }^{2}$
}

\begin{abstract}
Summary: Guedes L, Rebelo H, Oliveira R, Neves A - Regional Analgesia in Intensive Care.
Justifications and objectives: regional analgesia plays an important role in multimodal pain management in critically ill patients, minimizing patient discomfort and reducing the associated physiological and psychological stress. Lower doses of systemic opioids reduce some of its side effects, such as withdrawal syndrome, possible psychological changes, and gastrointestinal dysfunction. Despite these benefits, its use is controversial, as patients in intensive care units often have contraindications, such as coagulopathy, hemodynamic instability, and difficulty in neurological assessment and implementation of regional technique.
\end{abstract}

Content: The authors present a review of regional analgesia in intensive care, focusing on the main advantages and limitations of its use in critically ill patients, and describe the most commonly used regional techniques and its applicability.

Keywords: Analgesia; Anesthesia, Conduction; Pain; Intensive Care/complications.

@2012 Elsevier Editora Ltda. All rights reserved.

\section{INTRODUCTION}

Approximately $50 \%$ of critically ill nonsurgical patients report pain during hospitalization in intensive care units (ICUs) ${ }^{1}$. There are many causes of pain, such as underlying disease at admission, trauma, surgery, nursing care (mobilization, airway suction, physiotherapy), prolonged immobilization and invasive therapeutic procedures, diagnostic or monitoring ${ }^{2,3}$.

The method considered more reliable for assessing pain intensity and response to analgesia is indicated by the patient with the use of objective scales (Visual Analogue Scale, Visual Numeric Scale, Visual Descriptive Scale) ${ }^{4,5,6}$. It is often difficult or impossible to quantify the subjective experience of pain in critically ill patients due to the presence of the endotracheal tube, state of unconsciousness and/or administration of sedative drugs, which inhibit or preclude the application of these scales. Observation of behavioral responses (facial expression, agitation, posture) or physiological stress (blood pressure, heart rate, respiratory rate, diaphoresis, intracranial pressure) may be the only possible assessment of pain, but with large margin of error, as suffering and autonomic response to aggression result from activation of different zones of the central nervous system (CNS) with different sensitivity to noxious activation ${ }^{7}$.

Received from Hospital de São João, Portugal.

1. Anesthesiology Department, Hospital de São João, Entidade Pública Empresarial (EPE), Porto, Portugal

2.General Unit of Polyvalent Intensive Care, Hospital de São João, EPE, Porto, Portugal

Submitted on August 30, 2011

Approved on September 30, 2011.

Correspondence to:

Luísa Guedes, MD

Hospital de São João

Alameda Professor Hernani Monteiro

Porto, Portugal

E-mail: luisa_ferraz@hotmail.com
Effective analgesia in critically ill patients improves lung function, ventilatory weaning and early mobilization, and decreases the plasma levels of catecholamines and myocardial oxygen consumption ${ }^{8,9}$. Regional analgesia is particularly effective in achieving these objectives, mainly in multimodal analgesia in which the required doses of opioids are reduced to mitigate side effects 4,10

However, patients in intensive care often have contraindications, such as coagulation disorders, severe hypovolemia, hemodynamic instability, and difficult neurological assessment and implementation of the technique, which determines the use of regional analgesia and requires careful risk-benefit evaluation.

There are few published data on the use of regional analgesia in intensive care units, which hinders evidence-based decisions.

The aim of this paper is to present a review of regional analgesia in intensive care, focusing on the main advantages and limitations of its use in critically ill patients, and describe the most commonly used regional techniques and its applicability.

\section{METHODS}

Literature review was performed through search of Medline articles published in the last 12 years with the following keywords: "regional analgesia", "intensive care", "peripheral blocks" and "critically ill patients".

\section{REGIONAL ANALGESIA}

\section{Peripheral nerve block}

There are no prospective randomized controlled studies evaluating the use of peripheral nerve blocks for analgesia of critically ill patients. 
In polytraumatized patients in which orthopedic injuries of limbs are part of multiple lesions, the presence of severe pain, often accompanied by traumatic or iatrogenic altered consciousness, conditions the use of effective doses of opioids by fear of central depression after the use of high doses. Regional techniques for analgesia of upper and lower limbs can provide adequate pain control without central depression. Peripheral nerve blockade guided by ultrasound and/or neurostimulation and the use of stimulation catheters in sedated patients allow the reduction of complications associated with the technique and increase success rate ${ }^{11}$.

In a meta-analysis, Richman found that continuous peripheral nerve block promoted better analgesia with fewer side effects compared to analgesia with opioids ${ }^{12}$.

Analgesia for both shoulder and upper limb may be obtained through various approaches for brachial plexus blockade, particularly by interscalenic or axillary route. Continuous femoral nerve block is a good option in postoperative femoral neck fractures ${ }^{13,14}$. This technique, when combined with sciatic block, allows adequate analgesia for injuries affecting the entire lower limb.

In high-risk fractures, such as tibial and distal radius, epidural and peripheral nerve block may hinder the recognition of compartment syndrome in intensive care ${ }^{15}$. To minimize this risk, the indication for peripheral nerve block analgesia should be discussed with the surgical team, and intracompartmental pressure monitoring should be considered ${ }^{16}$.

Diagnosis of bacteremia caused by peripheral catheter infection in continuous analgesia techniques may be difficult to distinguish from worsening disease. The puncture site should be carefully inspected when administering the drug and, if infection is suspected, the catheter should be immediately removed. Microbiological analysis of the catheter-tip may be useful for guiding antibiotic therapy. To confirm suspicion associated bacteremia, blood cultures should be collected prior to the administration of empiric antibiotic therapy ${ }^{17}$.

The large volumes of local anesthetic used demands a carefully observation of the maximum recommended doses, especially when a combination of different blocks is used ${ }^{18}$.

Table I shows the main practical problems, indications, contraindications, and recommended doses for upper and lower limb blockade performed in the ICU.

\section{Epidural analgesia}

Epidural analgesia is the regional technique most frequently used in critically ill patients. There is no evidence of mortality reduction with its use, but several studies show that when compared to parenteral opioids it is at least equivalent regarding the outcome, ICU length of stay, and duration of ventilatory support. It is also reported that epidural analgesia reduces the incidence of paralytic ileus, improves analgesia and patient satisfaction in cases of thoracic trauma, abdominal surgery, vascular surgery, major orthopedic surgery, acute pancreatitis, cardiac surgery, and intractable angina pectoris $4,19,20$.

Pulmonary dysfunction after thoracic and abdominal surgery is mainly caused by pain that leads to diaphragmatic dysfunction and hypoventilation. These factors give rise to a reduction in functional residual capacity (FRC) and hypoxemia.

Table I - Main Indications, Contraindications, Practical Problems, and Recommended Doses for Upper and Lower Limb Blockade

\begin{tabular}{|c|c|c|c|c|}
\hline Technique & Indications & Contraindications & Practical Problems & Suggested Therapy \\
\hline $\begin{array}{l}\text { Axillary plexus } \\
\text { block }\end{array}$ & $\begin{array}{l}\text { Analgesia for hand } \\
\text { and forearm }\end{array}$ & Infection at puncture site & $\begin{array}{l}\text { Patient positioning } \\
\text { Neurological function } \\
\text { monitoring }\end{array}$ & $\begin{array}{l}\text { Ropivacaine } 0.2 \% \\
\text { Perfusion } 5 \mathrm{~mL} . \mathrm{h}^{-1} \\
10-20 \mathrm{~mL} \text { bolus, } 6 / 6 \mathrm{~h}\end{array}$ \\
\hline $\begin{array}{l}\text { Interscalene } \\
\text { plexus block }\end{array}$ & $\begin{array}{l}\text { Analgesia for } \\
\text { shoulder and } \\
\text { proximal arm }\end{array}$ & $\begin{array}{l}\text { Infection at puncture site } \\
\text { Contralateral phrenic nerve } \\
\text { palsy } \\
\text { Contralateral recurrent nerve } \\
\text { palsy } \\
\text { COPD (relative) }\end{array}$ & $\begin{array}{l}\text { Patient positioning } \\
\text { Neurological function } \\
\text { monitoring }\end{array}$ & $\begin{array}{l}\text { Ropivacaine } 0.2 \% \\
\text { Perfusion } 5 \mathrm{~mL} \cdot \mathrm{h}^{-1} \\
\text { Bolus } 10-20 \mathrm{~mL}, 6 / 6 \mathrm{~h}\end{array}$ \\
\hline $\begin{array}{l}\text { Femoral nerve } \\
\text { block }\end{array}$ & $\begin{array}{l}\text { Analgesia for } \\
\text { anteromedial thigh, } \\
\text { femur, and knee }\end{array}$ & $\begin{array}{l}\text { Infection at puncture site } \\
\text { Bypass femoropopliteal }\end{array}$ & $\begin{array}{l}\text { Patient positioning } \\
\text { Neurological function } \\
\text { monitoring }\end{array}$ & $\begin{array}{l}\text { Ropivacaine } 0.375 \%, 0.2 \%, 0.1 \% \\
\text { Levobupivacaine } 0.25 \%, 0.125 \% \\
\text { Bupivacaine } 0.125 \% \\
\text { Bolus } 20 \mathrm{~mL} \text {, each } 6-8 \mathrm{~h} \\
\text { Perfusion } 6-8 \mathrm{~mL}^{-1} \mathrm{~h}^{-1} \\
\left(0.1 \mathrm{~mL} . \mathrm{kg}^{-1} . \mathrm{h}^{-1}\right)\end{array}$ \\
\hline $\begin{array}{l}\text { Sciatic nerve block } \\
\text { (via popliteal) }\end{array}$ & $\begin{array}{l}\text { Analgesia for foot, } \\
\text { ankle, and leg }\end{array}$ & Infection at puncture site & $\begin{array}{l}\text { Patient positioning } \\
\text { Neurological function } \\
\text { monitoring }\end{array}$ & $\begin{array}{l}\text { Ropivacaine } 0.375 \%, 0.2 \%, 0.1 \% \\
\text { Levobupivacaine } 0.25 \%, 0.125 \% \\
\text { Bupivacaine } 0.125 \% \\
\text { Bolus } 20 \mathrm{~mL} \text {, each } 6-8 \mathrm{~h} \\
\text { Perfusion } 6-10 \mathrm{~mL} \cdot \mathrm{h}^{-1} \\
\left(0.05-0,1 \mathrm{~mL} \cdot \mathrm{kg}^{-1} . \mathrm{h}^{-1}\right)\end{array}$ \\
\hline
\end{tabular}


Table II - Main Indications and Therapeutic Approaches for Epidural Analgesia in Critically III Patients

\begin{tabular}{lll}
\hline $\begin{array}{l}\text { Thoracic epidural } \\
\text { Thoracic trauma }\end{array}$ & $\begin{array}{l}\text { Lumbar epidural } \\
\text { Orthopedic surgery of lower limbs }\end{array}$ & $\begin{array}{l}\text { Suggested Therapy } \\
\text { Local anesthetic }+ \text { opioid } \\
\text { Ropivacaine } 0.1 \% / 0.2 \%\end{array}$ \\
$\begin{array}{l}\text { Thoracic surgery } \\
\text { Abdominal surgery }\end{array}$ & $\begin{array}{l}\text { Lower limb trauma } \\
\text { Peripheral vascular disease of lower limbs }\end{array}$ & $\begin{array}{l}\text { Fentanyl } 2-4 \mathrm{mcg} \cdot \mathrm{mL}^{-1} \\
\text { Sufentanil } 0.5-1 \mathrm{mcg}^{-1} \mathrm{~mL}^{-1}\end{array}$ \\
Paralytic ileus & - & $\begin{array}{l}\text { Infusion of } 4-10 \mathrm{~mL}^{-1} \text {, according to catheter tip location and } \\
\text { dermatomes involved }\end{array}$ \\
$\begin{array}{l}\text { Pancreatitis } \\
\text { Unstable angina }\end{array}$ & - & $\begin{array}{l}\text { Thoracic level: } 0.5-1 \mathrm{~mL} \text { of LA per segment } \\
\text { Lumbar level: } 1-2 \mathrm{~mL} \text { of LA per segment }\end{array}$ \\
\hline
\end{tabular}

Table III - Absolute and Relative Contraindications to Epidural Catheter Placement

\begin{tabular}{ll}
\hline Absolute & Relative \\
\hline $\begin{array}{l}\text { Infection at puncture site } \\
\text { Patient's refusal }\end{array}$ & $\begin{array}{l}\text { Sepsis } \\
\text { Preexisting neurological deficits } \\
\text { (Demyelinating diseases) }\end{array}$ \\
$\begin{array}{ll}\text { Coagulopathy or other bleeding } \\
\text { disorders }\end{array}$ & $\begin{array}{l}\text { Stenotic valvular disease } \\
\text { Intracranial hypertension }\end{array}$ \\
Severe aortic stenosis & Spinal deformities \\
Severe mitral stenosis & Uncooperative patient \\
\hline
\end{tabular}

Decreased FRC may result in atelectasis, changes in ventilation/perfusion, and pulmonary complications in postoperative period, particularly pulmonary infection ${ }^{21}$. Epidural anesthesia, when compared to intravenous analgesia, increases FRC by $27 \%$ and decreases the rate of pulmonary complications ${ }^{22}$. On the other hand, by reducing the need for mechanical ventilation, iatrogenic, ventilator-associated pneumonia, length of hospital stay, and hospital costs are also reduced.

Table II shows the main indications for epidural analgesia in critically ill patients, as well as therapeutic approaches. Table III shows the absolute and relative contraindications to epidural catheter insertion.

\section{Complications}

The most common side effects of epidural analgesia are bradycardia and hypotension resulting from sympathetic blockade, which may be reduced by using low concentrations or incremental doses of local anesthetics. Other side effects of opioids are pruritus, nausea, vomiting, sedation and respiratory depression. Clonidine side effects are sedation, hypotension, and bradycardia. The addition of morphine, fentanyl, sufentanil or clonidine to epidural analgesia in intensive care should be considered individually and may be an advantage in critically ill patients, as it allows lower doses of local anesthetics, optimal analgesia, and fewer hemodynamic changes.
Positive pressure ventilation, particularly at high pressures, reduces venous return, may influence local anesthetic spread in thoracic epidural blocks, and favors a dispersion trend caudally ${ }^{23}$.

Studies have shown that the risk of infection associated with epidural anesthesia in intensive care appears to be low, and the presence of two local signs of inflammation is a strong predictor of local and epidural catheter infection ${ }^{24}$.

Antibiotic prophylaxis for placement of epidural catheter is not routinely recommended in scenarios of intra and extra intensive care, although some studies show a reduction in catheter colonization rates ${ }^{25}$. The use of maximum aseptic measures, similar to the placement of central venous catheters, is recommended and aslo reduces the risk of infections ${ }^{26}$. Catheter must be removed if signs of inflammation and/or pus at the site of infection are perceived, or if there is a suspected central nervous system infection.

The use of epidural catheter in patients with clotting disorders may be associated with the onset of epidural or subdural hematomas, whose diagnosis is difficult in critically ill patients. It is recommended that epidural catheter should be firmly secured to prevent accidental removal. If this occurs, it should be given particular attention to neurological monitoring. The placement of tunneled catheters may prevent its exteriorization during maneuvers for the positioning of a critically ill patient.

The proper positioning of epidural catheter in epidural space must be assessed carefully by aspiration before drug administration. This seems to be the most simple and secure approach to prevent intravascular injection of local anesthetic in critically ill patients, as they may have an altered response to administration of test dose with adrenaline, by the use of beta blockers, calcium channel blockers, clonidine, and endogenous and exogenous catecholamines ${ }^{7}$. As an option to this method of placement confirmation, electrical stimulation may be used via epidural catheter (Tsui test) or radiological confirmation after administration of radiopaque contrast into epidural space ${ }^{27}$. Intravascular injection of local anesthetics is associated with significant toxicity, which primarily affects the central nervous system (CNS) and is manifested by prodromal symptoms (dizziness, tinnitus, tongue paresthesia, perioral numbness, metallic taste, hearing and visual disorders) prior to seizures (by inhibitory pathway blockade) and central depression. Cardiovascular manifestations occur after the onset of signs and symptoms of CNS and are more frequent with the 
use of bupivacaine due to the long blockade duration of this fast-in-slow-out fashion. Systemic manifestations are related to the patient's acid-base status. The increase in $\mathrm{PaCO}_{2}$ and acidosis causes a reduction in seizure threshold and an increased rate of systemic toxic reactions. Hypercapnia increases cerebral blood flow and uptake of local anesthetics ${ }^{28}$.

Table IV - Most Frequent Complications Associated with Epidural Block

\begin{tabular}{|c|c|c|}
\hline $\begin{array}{l}\text { Associated with the } \\
\text { technique }\end{array}$ & $\begin{array}{l}\text { Associated with the } \\
\text { use of LA }\end{array}$ & $\begin{array}{l}\text { Associated with the } \\
\text { use of opioids }\end{array}$ \\
\hline $\begin{array}{l}\text { Dura mater puncture } \\
\text { Abscess, epidural } \\
\text { hematoma } \\
\text { Nerve injury }\end{array}$ & $\begin{array}{l}\text { Hypotension } \\
\text { Extended bilateral } \\
\text { motor and sensory } \\
\text { block } \\
\text { Cardiovascular and } \\
\text { central nervous } \\
\text { system toxicity }\end{array}$ & $\begin{array}{l}\text { Respiratory } \\
\text { Depression } \\
\text { Sedation } \\
\text { Nausea, vomiting } \\
\text { Pruritus }\end{array}$ \\
\hline
\end{tabular}

LA: local anesthetics.
Local toxicity should also be considered, for (1) Allergic reactions, most common with amino esters and related to presensitization mechanisms of para-aminobenzoic acid (PABA). Symptoms are predominantly urticarial skin rash, starting on the face and extending to the neck and chest, followed by intense itching, and anaphylactic shock. (2) Myotoxicity, related to the intramuscular administration of local anesthetic in high concentrations. (3) Neurotoxicity, common to all local anesthetics (more frequent with lidocaine) by accumulation of high concentrations of local anesthetics near nerve trunks (Cauda Equina Syndrome).

Table IV shows a summary of the most common complications associated with epidural block.

\section{Changes in hemostasis}

The techniques for regional analgesia in patients undergoing hemostasis inhibition therapy in scenarios of intra and extra intensive care should be guided according to existing recom-

Table V - Recommended Times for Suspension of Antiplatelet Agents in Neuraxial Blockade (Adapted from Fonseca C et al. ${ }^{30}$ with Author's Permission)

\begin{tabular}{|c|c|c|c|}
\hline \multirow[t]{3}{*}{ COX-1 INHIBITORS } & NSAIDs & Do not suspend & Do not suspend \\
\hline & Aspirin & Do not suspend & $\begin{array}{l}\text { Do not suspend. Start } 6-24 \text { hours after } \\
\text { NAB/catheter removal }\end{array}$ \\
\hline & Triflusal & Do not suspend & Do not suspend \\
\hline CAMP INHIBITORS & Dypiridamole & Do not suspend & Do not suspend \\
\hline \multirow[t]{3}{*}{ TIENOPYRIDINE DERIVATIVES } & Clopidogrel & 5 days & $\begin{array}{l}\text { Start } 6-24 \text { hours after NAB/ catheter } \\
\text { removal }\end{array}$ \\
\hline & Ticlopidine & 10 days & \\
\hline & Prasugrel & 7 days & \\
\hline \multirow[t]{3}{*}{ GP IIB/IIIA INHIBITORS } & Abcximab & 48 days & $\begin{array}{l}\text { Recommended not to start within } 4 \text { weeks } \\
\text { after surgery/NAB }\end{array}$ \\
\hline & Tirofiban & 8 days & Neurological monitoring, if necessary \\
\hline & Eptifibatide & 8 days & \\
\hline
\end{tabular}

NAB: Neuraxis blockade.

Table VI - Safety Recommendations Times for Handling Drug-treated Patients with Hemostasis Inhibitors

\begin{tabular}{|c|c|c|c|c|}
\hline Drugs & & $\begin{array}{l}\text { NAB } \\
\text { Safety times (hours) }\end{array}$ & $\begin{array}{l}\text { Start after NAB/ } \\
\text { catheter removal }\end{array}$ & Observations \\
\hline \multirow[t]{2}{*}{ LMWH } & Prophylactic & $12 \mathrm{~h}$ & $6 \mathrm{~h}$ & If $\mathrm{LMWH}>5$ days, Platelet count \\
\hline & Therapeutic & $24 h$ & $6 \mathrm{~h}$ & $\begin{array}{l}\text { Epidural catheter permanence not } \\
\text { recommended. If } \mathrm{LMWH}>5 \text { days, Platelet } \\
\text { count }\end{array}$ \\
\hline OAC & & INR $<1.5 ; \geq 4$ days & & $\begin{array}{l}\text { INR necessary }<1.5 \text { irrespective of } \mathrm{OAC} \\
\text { suspension time, which may vary from } 1-5 \text { days }\end{array}$ \\
\hline Fibrinolytics & & $24-36 h$ & $4 \mathrm{~h}$ & $\begin{array}{l}\text { NAB contraindicated in patients receiving } \\
\text { fibrinolytics }\end{array}$ \\
\hline Natural products & & & & No contraindications for NAB \\
\hline Fondaparinux & & $36 h$ & $12 \mathrm{~h}$ & $\begin{array}{l}\text { Increased security time is recommended if } \\
\text { creatinine clearance }<30 \mathrm{~mL} \text {. } \mathrm{min}^{-1}\end{array}$ \\
\hline
\end{tabular}

NAB: Neuraxis blockade; SC: Subcutaneous; UFH: Unfractionated heparin; LMWH: low molecular weight heparin; OAC: oral anticoagulant. Adapted from Fonseca C et al. ${ }^{30}$ with authors' permission. 
Table VII - Recommendations for Plexus/Peripheral Nerve block in Patients Treated with Hemostasis Inhibitors

\begin{tabular}{ll}
\hline No contraindications & Brachial plexus block \\
& Mid-humeral block \\
\hline \multirow{2}{*}{ Recommendations similar to the neuraxis } & Distal blocks \\
& Brachial plexus via interscalene \\
No contraindications & Braquial plexus via supraclavicular \\
& Braquial plexus via infraclavicular \\
Recommendations similar to the neuraxis & Femoral nerve block \\
& Iliac fascia block \\
& Distal sciatic block \\
& Lumbar plexus block \\
& Sciatic block, gluteal approach \\
& Sciatic block, anterior approach \\
& Sciatic block, parasacral approach
\end{tabular}

Adapted from Fonseca $\mathrm{C}$ et al ${ }^{30}$ with authors' permission.

mendations to minimize risks and increase safety. Tables $\mathrm{V}$, VI and VII present the current recommendations of the Portuguese Society of Anesthesiology validated by the College of the Anesthesiology Specialty to perform neuraxial blocks, peripheral blocks, and removal of catheters in patients undergoing antiplatelet and anticoagulant therapies ${ }^{29}$.

\section{DISCUSSION}

Regional analgesia for neuraxial or peripheral nerve block should be seen as effective and safe for critically ill patients, used alone or in multimodal context. It minimizes patient discomfort and reduces the physiological and psychological stress, as in non-critical patients. The reduced side effects of systemic opioids and sedatives allow early mobilization, rehabilitation, and improve patient satisfaction.

The presence of coagulation disorders of iatrogenic cause or in multiple organ failure is the main limitation to its use in critically ill patients. The recommendations for patients with hypocoagulation or under antiplatelet therapy should be followed in intensive care.

The use of regional analgesia in the ICU setting should consider the risk/benefit ratio due to the limited cooperation of the patient in the placement and monitoring. The indications for its use should be carefully and individually set according to patient's anatomy, clinical condition, presence of contraindications, and logistic conditions ${ }^{30}$.

To ensure the safety and efficacy, it is essential: a) training of health professionals (physicians, nurses, and physiotherapists) in the prevention and early detection of complications and problems; b) creating a detailed record of the assessment of pain and complications, enabling a real time audit of the efficacy and safety of therapies used and adjusting them on time; c) development of protocols and safety rules that extraordinarily anticipate possible situations, allowing the optimization of therapeutic regimens.

Literature shows that regional analgesia in critically ill patients is very little used, despite evidence of favorable outcomes. Still, the available evidence is limited to case reports, cut-off studies, or experts' opinion and is based mainly on studies designed for intraoperative management of surgical patients in whom admission to intensive care is part of the perioperative course. There are no studies specifically designed to evaluate the use of regional analgesia in this context 4,7 . To confirm the promising results found in literature, it is necessary to evaluate prospectively the advantages and limitations of epidural and regional blocks that allow the precise definition of its role in intensive care analgesia. 
9. Lewis KS, Whipple JK, Michael KA, Quebbeman EJ - Effect of analgesic treatment on the physiological consequences of acute pain. Am J Hosp Pharm, 1994;51(12):1539-1554.

10. Clark F, Gilbert HC - Regional analgesia in the intensive care unit. Principles and practice. Crit Care Clin, 2001;17(4):943-966.

11. Marhofer P, Greher M, Kapral S - Ultrasound guidance in regional anaesthesia. Br J Anaesth, 2005;94:7-17.

12. Richman JM, Liu SS, Courpas G et al. - Does continuous peripheral nerve block provide superior pain control to opioids? A meta-analysis. Anesth Analg, 2006;102:248-257.

13. Finlayson BJ, Underhill TJ - Femoral nerve block for analgesia in fractures of the femoral neck. Arch Emerg Med, 1988;5:173-176.

14. Tan TT, Coleman MM - Femoral blockade for fractured neck of femur in the emergency department. Ann Emerg Med, 2003;42: 596-597.

15. Davis ET, Harris A, Keene D et al. - The use of regional anaesthesia in patients at risk of acute compartment syndrome. Injury, 2006;37:128133.

16. Kostler W, Strohm PC, Sudkamp NP - Acute compartment syndrome of the limb. Injury, 2004;35:1221-1227.

17. Furuno JP, Perencevich EN, Johnson JA et al. - Methicillin-resistant Staphylococcus aureus and vancomycin-resistant enterococci cocolonization. Emerg Infect Dis, 2005;11:1539-1544.

18. Rosenberg PH, Veering BT, Urmey WF - Maximum recommended doses of local anesthetics: a multifactorial concept. Reg Anesth Pain Med, 2004;29:564-575.

19. Jorgensen H, Wetterslev J, Moiniche S, Dahl JB. Epidural local anaesthetics versus opioid-based analgesic regimens on postoperative gastrointestinal paralysis, PONV and pain after abdominal surgery. Cochrane Database Syst Rev 2000;4:CD001893.

20. Peyton PJ, Myles PS, Silbert BS et al. - Perioperative epidural analgesia and outcome after major abdominal surgery in high-risk patients. Anesth Analg, 2003;96:548-554.

21. Ballantyne JC - Does epidural analgesia improve surgical outcome? $\mathrm{Br} J$ Anaesth, 2004;92:4-6.

22. Ballantyne JC, Carr DB, de Ferranti S et al. The comparative effects of postoperative analgesic therapies on pulmonary outcome. Anest Analg, 1998;86:598-612.

23. Visser WA, Gielen MJ, Giele JL - Continuous positive airway pressure breathing increases the spread of sensory blockade after low-thoracic epidural injection of lidocaine. Anesth Analg, 2006;102:268-271.

24. Darchy B, Forceville X, Bavoux E, Soriot F, Domart Y - Clinical and bacteriologic survey of epidural analgesia in patients in the intensive care unit. Anesthesiology, 1996;85(5):988-998.

25. Morin AM, Kerwat KM, Klotz M et al. - Risk factors for bacterial catheter colonization in regional anaesthesia. BMC Anesthesiol, 2005;5:1.

26. Herwaldt LA, Coffin SA, Schulz-Stübner S - Nosocomial infections associated with anesthesia. Em: Hospital Epidemiology and Infection Control. Third Edition. Mayhall CG, ed. Philadelphia, Lippincott, Williams \& Wilkins, 2004, pp 1073-1117.

27. Tsui BC, Guenther C, Emery D, Finucane B - Determining epidural catheter location using nerve stimulation with radiological confirmation. Reg Anesth Pain Med, 2000;25:306-309.

28. Borges S, Azevedo A, Bezerra M, Canas M - Efeitos adversos dos anestésicos locais. CAR, 2001;28-32.

29. Fonseca C, Lages N, Correia C et al. - II Reunião de Consenso de Doentes medicados com fármacos inibidores da hemostase propostos para anestesia locorregional. Rev SPA, 2010;19(2):12-29.

30. Burton AW, Eappen $S$ - Regional anesthesia techniques for pain control in the intensive care unit. Crit Care Clin, 1999;15:77-1588.

5. Fraser GL, Riker RR - Monitoring sedation, agitation, analgesia, and delirium in critically ill adult patients. Crit Care Clin, 2001;17(4):967987.

6. Melzack R, Katz $\mathrm{J}$ - Pain measurement in persons in pain. In Wall PD, Maelzack R (eds): Textbook of pain, Edinburgh, Churchill Livingstone 1999, pp. 337-351.

7. Schulz-Stübner $S-$ The critically ill patient and regional anesthesia. Curr Opin Anaesthesiol, 2006;19(5):538-44.

8. Epstein J, Breslow MJ - The stress response of critical illness. Crit Care Clin, 1999;15(1):17-33. 